Available online at website :

http:/ / e-journal.adpgmiindonesia.com/index.php/jmie

JMIE: Journal of Madrasah Ibtidaiyah Education, 5(2), 2021, 173-183

\title{
PROBLEMATICS OF LITERATION LEARNING ELEMENTARY SCHOOLS IN THE NEW NORMAL ERA
}

\author{
Zaenal Abidin ${ }^{1,5)}$, Tatang Herman ${ }^{2}$, Choiriyah Widyasari ${ }^{3)}$ Fatimah Nur Ismiyasari ${ }^{4}$ ) \\ Universitas Muhammadiyah Surakarta $1,3,4)$ \\ Universitas Pendidikan Indonesia ${ }^{2,5}$ \\ E-mail: za825@ums.ac.id ${ }^{1)}$, tatangherman@upi.edu'2),cw272@ums.ac.id ${ }^{3)}$, \\ q200180022@student.ums.ac.id ${ }^{4}$
}

Submit: 16 Januari 2021, Revisi: 1 Oktober 2021, Approve: 8 November 2021

\begin{abstract}
This study aims to describe literacy learning problems for elementary school students in the pandemic. This type of research is qualitative research. The research design was a case study at MI Muhammadiyah Kartasura. The subjects of this study were teachers, students, and parents of upper-class students. Data collection techniques with observation, interviews, and documentation. The research data validation was carried out by data triangulation. The data analysis model uses interactive analysis. The results showed that literacy learning in elementary schools has many problems. Difficulty of implementing student literacy habits when studying at home, the low reading interest of students, lack of references owned by teachers, and teachers' mastery in the use of technology. Other problems have come from external, unattractive reading, difficulty accessing reading material, internet signal, and some parents do not have time to assist children in a task. The conclusion of this study is to solve the problem of literacy learning for elementary school students. It requires collaboration between teachers, students, and parents of students and digital literacy that is more creative and innovative to motivate students to read, in ordet to remain productive even though learning from home in the new habituation.
\end{abstract}

Keywords: literacy learning, elementary school, new normal era

Pengutipan: Zaenal Abidin, dkk. (2021). Problematics of Literation Learning Elementary Schools in the New Normal Era. JMIE: Journal of Madrasab Ibtidaiyah Education, 5(2), 2021, 173 183. jmie.v5i2.295.

Permalink/DOI: http:/ /dx.doi.org/10.32934/jmie.v5i2.295 


\section{INTRODUCTION}

Currently, almost all countries in various parts of the world are affected by the coronavirus outbreak (Covid-19). The WHO China office first reported that this virus was endemic in Wuhan, China, and has spread worldwide. On January 30, 2020, the World Health Organization (WHO, 2020) stated that many of the international community was experiencing a health emergency. A virus known as Covid-19 (The Corona Virus Disease) has spread in several countries globally, including Indonesia. This virus is easily applied and transmitted through droplets of saliva or mucus from coughing or sneezing (droplets) and air. It tends not to be influenced by climate variations in the world (Ramadhan, 2020).

In Indonesia, on March 17, 2020, the President of the Republic of Indonesia, Joko Widodo, declared an emergency response to the Covid-19 virus. This virus has had a tremendous impact on all sectors in Indonesia, including the education sector. Through the task force to accelerate the handling of covid-19, the Government calls on all people to implement physical distancing and social distancing in all types of activities, including activities at school that has initially been carried out face-to-face to become distance learning. Distance learning is a teaching and learning process carried out remotely through various communication media or information and communication technology (Kefalis \& Drigas, 2019). Currently, the communication media that is inseparable from the world of education is digital technology. Digital technology includes various computer hardware and software such as cell phones, web tools, application software, communication, and storage services (Fessakis et al., 2018; Kandakatla et al., 2020)

All education components, especially teachers and students, can use digital technology to carry out various teaching and learning activities during the Covid-19 pandemic. The ease of using digital technology keeps teaching and learning activities going. It is supported by the existence of various learning site platforms. It has sprung up along with digital technology such as learning houses, our desks, ICando, Indonesia X, Google for education, excellent classes, Microsoft Office 365, Quipper school, teachers room, your school, Zenius, and Cisco Webex (Ashari, 2020; Istiq'faroh et al., 2020). The entire learning site platform can be accessed free of charge via an internet connection. However, its use requires proper literacy skills and mastery in using technology to sort out the accurate information when using the internet.

Mastery of literacy is an important thing needed for participation in the 21 st century. It follows the three skills that the 21 st-century generation must master, which include competence, character, and literacy (Zaenal Abidin et al., 2020; Rizki \& Priatna, 2019). The era of the 21st century or the alpha generation is a generation that lives in an environment covered by media and technology (Afrin et al., 2020; Nur Utami \& Mustadi, 2017). In Indonesia, from 2001 to 2100 , entering the 21 st century. However, in 2020 this must be constrained because of the covid-19 virus, which has not ended. In the absence of any signs of an end, the Government, 
through a press release delivered ( $\mathrm{Z}$ Abidin et al., 2021), argued that the Government would implement a new normality by maintaining distance, diligently washing hands using masks.

The new normal is to reopen economic, social, and public activities on a limited basis by still paying attention to health protocols related to Covid-19. The new normality was first put forward on 10 June 2020 by the WHO Indonesia Situation Report. In his report, he appealed to all people to reduce activities outside the home and work from home (Wiryanto, 2020). It is supported by the President of the Republic of Indonesia's policy that appeals to the public to work, study and worship from home to cut the spread of the Covid-19 virus. As a form of support for the Government regarding efforts to cut the spread of the virus, finally, the Minister of Education and Culture Nadiem Makarim appealed to all levels of education to carry out the learning process at home (study from home) online by utilizing digital technology.

Education will continue to experience changes (Zaenal Abidin \& Jupri, 2017; Aksakal, 2015; Fessakis et al., 2018). The more in the future, there will be many demands that we will face, considering that we are currently in the Covid-19 pandemic. Therefore, digital technology in the world of education is very supportive in developing student competence and character. One of them is by creating a reading culture. Reading culture is better known as literacy (Murtono, 2012). Literacy will survive if there is a collaboration with learning (Bauer et al., 2020). However, currently, the literacy culture usually carried out in the classroom through education using offline books has turned into digital books online using various e-books on various literacy learning platform sites. The following is a digital literacy learning application recommended by the Ministry of Education and Culture through the school literacy movement book (Antoro, 2017) and a free e-book access site platform.

Table 1. Free e-book site platforms

\begin{tabular}{|c|c|c|}
\hline No & Platform & Alamat Situs \\
\hline 1 & Kemendikbud & http://buku.kemdikbud.go.id/ \\
\hline 2 & Goggle Scholar & https://scholar.google.co.id/ \\
\hline 3 & Gerakan Literasi Nasional & https://gln.kemdikbud.go.id \\
\hline 4 & Ganeca Digital & https://ganecadigital.com/ \\
\hline 5 & Perpustakaan Nasional & https://www.perpusnas.go.id/ \\
\hline 6 & Open Library & https://openlibrary.org/ \\
\hline 7 & Feedbooks & http://www.feedbooks.com/publicdomain \\
\hline 8 & Bookboon.com & https://bookboon.com/ \\
\hline 9 & Project Gutenberg & http://www.gutenberg.org/ \\
\hline 10 & The Literature Network & http://www.online-literature.com/ \\
\hline 11 & Read Print & http://www.readprint.com/ \\
\hline
\end{tabular}

The various e-book site platforms above can be used for free through internet networks. Integrating internet usage can develop student literacy (Leu et al., 2017). In the new habituation, literacy can be carried out comprehensively. Literacy must not just stop or face the demands of the obligation to study at home. However, literacy must continue to run, 
considering that education will continue to change, and the challenges in the future will be graver. Unfortunately, if you look at the International Student Assessment Program (PISA) survey results announced in early December 2016, the PISA score for reading increased by 1 point from 396 to 397 (Baldi et al., 2007). These results show that understanding and using readings in Indonesian children aged 9-14 years is in the bottom ten ranks. Furthermore, the Indonesia National Assessment Program (INAP) explains that reading, math, and science skills for elementary school children is low. It was showing $46.83 \%$ for reading skills.

Based on the survey results, Indonesia's literacy is still very low, especially when some people in Indonesia suffer from the coronavirus outbreak. It is important to familiarize students with setting aside time for offline and online literacy to enrich their knowledge and insights so that they are not left behind and can continue to exist following the development of education in the new normal era. In line with Permendikbud No. 23 of 2015, schools need to set aside time periodically for the habit of reading as part of growing student character. The 21 st-century generation must master literacy as the modules and training guidelines for the national literacy movement (Chodidjah, 2017). It has been agreed with the Word Economic Forum (2015), namely literacy in literacy, numeracy, scientific literacy, ICT literacy, financial literacy, and cultural \& citizenship literacy.

Laksono (2018) also adds four literacies: health literacy, safety literacy, criminal literacy, and gesture literacy. Besides, Nugraha and Dian (2020) added two literacies, namely ecological literacy and environmental literacy. The implementation of literacy today is not easy. There are many obstacles faced by both teachers, students, and parents of students. One of the challenges is the students' low reading interest. It is in line with Hamdah's (2018) research, where children often hold devices to play rather than open books. Nearly 70 million children use gadgets every day, so special assistance from parents is needed to surf the internet.

One school that has implemented a reading culture habit is MI Muhammadiyah PK Kartasura. Based on the observations and interviews at MI Muhammadiyah PK Kartasura in the era of new normal culture or literacy habits, upper-class students experienced several obstacles. Among the challenges faced by some teachers, such as lack of mastery of technology, difficulty finding free e-book platform sites, cooperation between teachers and parents. However, students and parents also experience less varied books, no feedback provided by the teacher, limited time for parents to accompany children, and limited internet connection. Therefore, good cooperation between teachers, students, and parents is needed so that character building and character through literacy habituation in the new normal era can run effectively. Based on the description presented above, the researcher will examine literacy learning problems in the new normal era for upper-class students at MI Muhammadiyah PK Kartasura. 


\section{METHODS}

This research is qualitative research using a case study design. This study explores and describes in detail and comprehensively the social situation (Sutama, 2019) about literacy learning problems in the new normal era of elementary school students. In qualitative research, researchers record the findings or phenomena encountered, then carry out an analysis of various documents found in the field, and finally compile a detailed research report (Hadi, 2016). This research was conducted from July to August 2020. The research site was at MI Muhammadiyah Kartasura. The subjects of this study were teachers, students, and parents of upper-class students. This study was limited to upper-class students (4, 5, and 6 grades).

Data collection techniques with observation, interviews, and documentation. Statements were made to observe literacy learning for elementary students in the new normal era. Talks in this study were conducted in-depth with teachers, students, and parents through face-to-face and WhatsApp applications. The documentation in this study documents the data in the form of a list of student presence, the student literacy learning process, the results of interviews and photos to support elementary school students' literacy problems in the new normal era. The validation of the research data was carried out by triangulating the data (source). The research data analysis technique was carried out by using qualitative analysis techniques. The data analysis model used the interactive model analysis model of Miles and Huberman. In the qualitative data analysis model, activities are carried out continuously until completion. Activities in data analysis include data reduction, display data, and conclusion drawing/verification.

The data that will be reduced in this study is information obtained from collecting observation data and interviews related to literacy learning for elementary school students in the new normal era. After the data is reduced, the data is displayed (data presentation). In presenting the data, the researcher sorts, organize, and connects data or information by type or category to fit the problems and temporary conclusions (Sugiyono, 2016). Then, concluding the data displayed, the researcher will draw conclusions related to the data. However, if there are irregularities in completing, the researcher will verify the data reduction and data presentation.

\section{RESULTS AND DISCUSSION}

Based on the interview results, it was found that teachers, students, and parents faced several obstacles in applying literacy learning in the new normal era. The following are some of the challenges presented in this study include:

\section{a. Literacy problems faced by teachers}

The fourth-grade teacher explains the obstacles faced in learning literacy in the new normal era is the difficulty of accessing free e-book sites on the internet, limited special 
assistance from parents when children learn and literate, little mastery of using parental devices access recommended e-books by the teacher.

The fifth-grade teacher explains the obstacles faced in learning literacy in the new normal era is the limited literacy monitoring of children, unable to explain and understand directly to children the meaning of words that are difficult to read.

The sixth teacher explains the obstacles faced in literacy learning in the new normal era, "Low reading interest of students, lack of free e-book references, limited parental assistance including supervision in using devices in the learning process."

\section{b. Literacy problems faced by students}

Based on the interviews with all fourth-grade students, the researcher underlined an essential point regarding the obstacles faced in learning literacy in the new normal era because the books do not vary and sometimes do not have pictures, parents bring cellphones, limited internet quota, often only using storybooks.

Based on interviews with all fifth-grade students, the researcher underlined essential points regarding the obstacles faced in learning literacy in the new normal era. They often feel bored when reading at home, limited access to reading material, little assistance from parents, limited internet quota.

Based on the interviews with all sixth-grade students, the researcher underlined essential points regarding the obstacles faced in learning literacy in the new normal era: the difficulty of understanding the meaning of words in reading. The reading sources do not vary. There is no feedback from the teacher.

\section{c. Literacy problems faced by parents}

Based on interviews with all fourth-grade parents, the researcher underlined an essential point regarding the obstacles faced in literacy learning. In the new normal era, challenging to get children to read, limited internet quota, cellphones are often brought to work, uninspired children tend to be lazy. Laziness when asked to read.

Based on interviews with all fifth-grade parents, the researcher underlined an essential point regarding the obstacles faced in learning literacy. The new normal era, is the absence of various e-books so that children get bored and lazy to read, limited mastery of accessing the internet, little knowledge, and parental insight.

Based on interviews with all parents in grade VI, the researcher underlined essential points regarding the obstacles faced in learning literacy. In the new normal era, limited time accompanying children to learn and literacy, little supervision when children play with gadgets; instead, they see YouTube or play games.

From the exposure of teachers, students, and parents regarding the problems of literacy learning, researchers also interviewed teachers, students, and parents regarding solutions to 
overcome these obstacles so that literacy learning in the new normal era can be beneficial and can help in shaping the character and character of students. Some of these solutions are presented in the following table.

Table 2. Solutions to the obstacles

\begin{tabular}{|c|c|c|c|}
\hline \multirow{2}{*}{ Class } & \multicolumn{3}{|c|}{ Solution for } \\
\hline & Teacher & Students & Parents \\
\hline 4 th grade & $\begin{array}{l}\text { Looking for various information } \\
\text { about free e-book sites } \\
\text { recommended for students with } \\
\text { literacy at home, parents must } \\
\text { provide particular time to } \\
\text { accompany children to learn and } \\
\text { literacy, provide tutorials, or } \\
\text { access e-book platform sites for } \\
\text { parents. }\end{array}$ & $\begin{array}{l}\text { There are various } \\
\text { books, free e- } \\
\text { books available. } \\
\text { Parents have time } \\
\text { to accompany } \\
\text { them to study and } \\
\text { read at home. }\end{array}$ & $\begin{array}{l}\text { There are } \\
\text { recommendations for } \\
\text { free e-book sites for } \\
\text { students with literacy at } \\
\text { home, coordinating } \\
\text { with teachers regarding } \\
\text { students' low reading } \\
\text { interest, giving rewards } \\
\text { and punishments when } \\
\text { students do not want to } \\
\text { or are lazy to read. }\end{array}$ \\
\hline 5 th grade & $\begin{array}{l}\text { Monitoring student literacy every } \\
\text { day so that students' difficulties } \\
\text { in understanding the meaning of } \\
\text { words or sentences that are } \\
\text { difficult to read can be resolved } \\
\text { immediately. Monitoring can be } \\
\text { done through the WhatsApp } \\
\text { application or other online } \\
\text { learning applications. }\end{array}$ & $\begin{array}{l}\text { Free e-books are } \\
\text { available, tutorials } \\
\text { are available, or } \\
\text { access reading } \\
\text { material motivates } \\
\text { teachers and } \\
\text { parents to be } \\
\text { enthusiastic about } \\
\text { reading. }\end{array}$ & $\begin{array}{l}\text { There are various e- } \\
\text { books, tutorials, or how } \\
\text { to access e-book } \\
\text { platform sites. There } \\
\text { are explanations from } \\
\text { the teacher through } \\
\text { videos or face-to-face } \\
\text { online learning } \\
\text { applications related to e- } \\
\text { books that students will } \\
\text { read. }\end{array}$ \\
\hline 6th grade & $\begin{array}{l}\text { Provide and recommend } \mathrm{e}- \\
\text { books so that students are } \\
\text { motivated to read, foster good } \\
\text { cooperation between teachers } \\
\text { and parents, coordinate with } \\
\text { parents regarding student } \\
\text { guidance time when studying. } \\
\text { Literate at home, there is a } \\
\text { collaboration between teachers } \\
\text { and students, and parents. }\end{array}$ & $\begin{array}{l}\text { There is daily } \\
\text { monitoring from } \\
\text { the teacher. There } \\
\text { is a video } \\
\text { explanation from } \\
\text { the teacher when } \\
\text { students find the } \\
\text { meaning of a tricky } \\
\text { word, giving } \\
\text { rewards and } \\
\text { feedback to make } \\
\text { reading more } \\
\text { enthusiastic. }\end{array}$ & $\begin{array}{l}\text { Time management so } \\
\text { that children can } \\
\text { accompany and learn } \\
\text { and literate using } \\
\text { gadgets, coordinate } \\
\text { with teachers regarding } \\
\text { the development of } \\
\text { student literacy at } \\
\text { home. }\end{array}$ \\
\hline
\end{tabular}

Based on the explanation above, the study results show that the problems with literacy learning in the new normal era are very diverse. Therefore, special handling is needed to overcome the various difficulties of literacy learning experienced by teachers, students, and 
parents. The way that can be done is to strengthen cooperation between teachers, students, and parents of students and the availability of digital literacy that is more creative and innovative to motivate students to read to remain productive even though learning from home in the new normal era (Fessakis et al., 2018; Onah \& Sinclair, 2017; Qvist et al., 2015; Şimşek \& Direkci, 2020). Also, the need to appreciate student literacy activities is a critical point to motivate students to read (Hendroanto et al., 2018; Niss, 2015). This form of appreciation can be carried out through various activities such as inviting students to make works such as short stories, poetry, or storytelling images (comics), publishing their work in book form, holding writing competitions, and giving rewards to students (Şimşek \& Direkci, 2020; Uçar et al., 2017).

It is in line with the module of the Ministry of Education and Culture (Antoro, 2017). One of the best ways to stimulate student interest and enthusiasm in literacy is to collect student and teacher written works. Also, the digital application of family and community literacy can motivate students to literate at home. It is consistent with Sutrisna (2020) research that parents can take advantage of family and community literacy with children at home by building interactions between parents and children in the use of digital literacy in the form of discussions and sharing positive literacy to motivate students in reading.

\section{CONCLUSION}

New normal, a social change that brings people in all parts of the world whenever and wherever to always pay attention to health protocols to prevent the Covid-19 virus. One of the sectors affected by this virus is the education sector. All levels of education are directed to study from home (study from home). No exception in literacy learning. Literacy is one of the skills that must be possessed in the 21 st century. Literacy helps students prepare for new challenges and foster good character and character for students. However, in the new normal era, the implementation of literacy experienced several problems. Teachers, students, and parents experienced these problems.

The problems experienced by teachers include the low reading interest of students. It is difficult to access free e-book sites on the internet and limited special assistance from parents when children learn. Little mastery of using parental devices to access e-books recommended by teachers, and unable to explain and understand directly to children the meaning of words that are difficult to read. Students' problems are difficulty understanding the meaning of words in reading, reading sources that do not vary, the absence of feedback (feedback) from the teacher, limited access to reading material, little assistance from parents, limited internet quota. Parents' problems are the difficulty of getting children to read and limited internet quota. The absence of various e-books so that children get bored and lazy to read. Little mastery of accessing the internet, limited knowledge and insight of parents, limited time to accompany them, children learn and literate. 


\section{REFERENCES}

Abidin, Z, Herman, T., Jupri, A., \& Farokhah, L. (2021). Gifted Children's Mathematical Reasoning Abilities on Problem-Based Learning and Project-Based Learning Literacy Gifted Children 's Mathematical Reasoning Abilities on Problem-Based Learning and Project-Based Learning Literacy. https://doi.org/10.1088/1742-6596/1720/1/012018

Abidin, Zaenal, \& Jupri, A. (2017). the Use of Multiliteration Model To Improve Mathematical Connection Ability of Primary School on Geometry. IJ AEDU-International E-Journal of Advances in Education, III(9), 603-610. https://doi.org/10.18768/ijaedu.370429

Abidin, Zaenal, Utomo, A. C., Pratiwi, V., Farokhah, L., Surakarta, U. M., Jakarta, U. B., \& Jakarta, U. M. (2020). PROJECT-BASED LEARNING - LITERACY IN IMPROVING STUDENTS 'MATHEMATICAL REASONING ABILITIES IN. 4(1), 39-52.

Afrin, R., Zaenal, P., Efi, A., Yusnia, R., \& Afifah, N. (2020). Using the Heroes Puppets as the Learning Media for Elementary School Students. 491(Ijcah), 367-371.

Aksakal, N. (2015). Theoretical View to The Approach of The Edutainment. Procedia - Social and Behavioral Sciences, 186(January), 1232-1239. https://doi.org/10.1016/j.sbspro.2015.04.081

Antoro, B. (2017). Gerakan literasi sekolah: dari pucuk hingga akar: sebuab refleksi. Kementerian Pendidikan dan Kebudayaan, Direktorat Jenderal Pendidikan Dasar dan Menengah.

Ashari, M. (2020). Proses Pembejalaran Daring di Tengah Antisipasi Penyebaran Virus Corona Dinilai Belum Maksimal.

Bauer, E., Compton-Lilly, C., Li, G., \& Razfar, A. (2020). Community, Collaboration, and the Co-Construction of Learning: JLR as a Space for Literacy Dialogue.

Baldi, S., Jin, Y., Skemer, M., Green, P. J., \& Herget, D. (2007). Highlights From PISA 2006: Performance of U.S. 15-Year-Old Students in Science and Mathematics Literacy in an International Context. Ies, 1-9.

Chodidjah, I. (2017). Modul dan Pedoman Pelatihan Fasilitator Gerakan Literasi Nasional. Jakarta: Kemendikbud.

Fessakis, G., Karta, P., \& Kozas, K. (2018). Designing math trails for enhanced by mobile learning realistic mathematics education in primary education. International Journal of Engineering Pedagogy, 8(2), 49-63. https://doi.org/10.3991/ijep.v8i2.8131

Hadi, Sumasno. (2016). Pemeriksaan Keabsahan Data Penelitian Kualitatif pada Skripsi. Jurnal Ilmu Pendidikan. No (1) hlm 74-79.

Hendroanto, A., Istiandaru, A., Syakrina, N., Setyawan, F., Prahmana, R. C. I., \& Hidayat, A. S. E. (2018). How Students Solves PISA Tasks: An Overview of Students' Mathematical Literacy. International Journal on Emerging Mathematics Education, 2(2), 129. https://doi.org/10.12928/ijeme.v2i2.10713

Istiq'faroh, N., Suhardi, S., Mustadi, A., \& Ahdhianto, E. (2020). The effect of indonesian folktales on fourth-grade students' reading comprehension and motivation. Elementary Education Online, 19(4), 2149-2160. https://doi.org/10.17051/ilkonline.2020.763772

Kandakatla, R., Berger, E. J., Rhoads, J. F., \& DeBoer, J. (2020). Student perspectives on the learning resources in an Active, Blended and Collaborative (ABC) pedagogical environment. International Journal of Engineering Pedagogy, 10(2), 7-31. https://doi.org/10.3991/ijep.v10i2.11606

Kefalis, C., \& Drigas, A. (2019). Web based and online applications in STEM education. International Journal of Engineering Pedagogy, 9(4), 76-85. 
https:// doi.org/10.3991/ijep.v9i4.10691

Kurniawan, A. R., Chan, F., Abdurrohim, M., Wanimbo, O., Putri, N. H., Intan, F. M., \& Samosir, W. L. S. (2019). Problematika Guru Dalam Melaksanakan Program Literasi Di Kelas IV Sekolah Dasar. EduStream: Jumal Pendidikan Dasar, 3(2), 31-37.

Laksono, K. (2018). Strategi Literasi dalam Pembelajaran di Sekolah Menengah Pertama (Edisi II, 2018). Jakarta: Satgas GLS Ditjen Dikdasmen Kementerian Pendidikan dan Kebudayaan

Leu, D.J., Kinzer, C. K., Coiro, J., Castek, J., \& Henry, L. A. (2017) New Literacies: A DualLevel Theory of the Changing Nature of Literacy, Instruction, and Assessment. Journal of Education, 197 (2), 1-18. https://doi.org/10.1177/002205741719700202

Murtono. (2012). Pengaruh Model Pembelajaran Kooperatif Circ, Jigsaw, dan STAD. Kajian Linguistik Dan Sastra, Vol. 24(1), 187-198.

Niss, M. (2015). Mathematical Literacy. The Proceedings of the 12th International Congress on Mathematical Education, 409-414. https://doi.org/10.1007/978-3-319-12688-3_31

Nugraha, D., \& Octavianah, D. (2020). Diskursus Literasi Abad 21 di Indonesia. Jurnal Pendidikan Edutama, 7(1), 107-126.

Nur Utami, K., \& Mustadi, A. (2017). Pengembangan Perangkat Pembelajaran Tematik Dalam Peningkatan Karakter, Motivasi, Dan Prestasi Belajar Siswa Sekolah Dasar. Jurnal Pendidikan Karakter, 7(1), 14-25. https://doi.org/10.21831/jpk.v7i1.15492

OECD. (2016). PISA 2015 Assessment and Analytical Framework: Science, Reading, Mathematic and Financial Literacy. Paris: OECD Publishing.

Onah, D. F. O., \& Sinclair, J. E. (2017). Assessing Self-Regulation of Learning Dimensions in a Stand-alone MOOC Platform. International Journal of Engineering Pedagogy (IJEP), 7(2), 4. https:// doi.org/10.3991/ijep.v7i2.6511

Qvist, P., Kangasniemi, T., Palomäki, S., Seppänen, J., Joensuu, P., Natri, O., Närhi, M., Palomäki, E., Tiitu, H., \& Nordström, K. (2015). Design of Virtual Learning Environments: Learning Analytics and Identification of Affordances and Barriers. International Journal of Engineering Pedagogy (IJEP), $5(4), 64$. https:// doi.org/10.3991/ijep.v5i4.4962

Ramadhan, R. (2020). Sebaran Kasus Virus Corona Covid-19 di 34 Provinsi Indonesia Jumat 25 Desember 2020, Tambah 7.259. ZONABANTEN.Com.

Rizki, L. M., \& Priatna, N. (2019). Mathematical literacy as the 21 st century skill. Journal of Physics: Conference Series, 1157(4). https://doi.org/10.1088/1742-6596/1157/4/042088

Şimşek, B., \& Direkci, B. (2020). In-game language usages of students playing online games: The sample of league of legends*. Elementary Education Online, 19(4), 2042-2052. https://doi.org/10.17051/ilkonline.2020.763315

Sugiyono. (2016). Metode Penelitian Kuantitatif, Kualitatif dan R\&D. Bandung: CV. Alfabeta.

Sutama. (2019). Metode Penelitian Pendidikan. Jakarta: Grasindo

Sutrisna, I Putu Gede. (2020). Gerakan Literasi Digital pada Masa PAndemi Covid-19. Jurnal Stilistika Vol. 8 No (2) ISSN-P 2089-8460, ISSN-E 2621-3338 Doi: $10.5281 /$ zenodo. 3884420

Uçar, F. M., Uçar, M. B., \& Çalişkan, M. (2017). Investigation of gifted students' problemsolving skills. Journal for the Education of Gifted Young Scientists, 5(3), 1-14. https://doi.org/10.17478/JEGYS.2017.61

WEF \& BCG (World Economic Forum \& The Boston Consulting Group). (2015). New Vision 
for Education: Unlocking the Potential of Technology. Cologny/Geneve: World Economic Forum. Diakses dari: http://www3.weforum.org/docs/WEF USA NewVisionforEducation Report2015.pdf

WHO. (2020). WHO Coronavirus Disease (COVID-19) Dashboard. Https:/ Covid19.Who.Int/.

Wiryanto. (2020). Proses Pembelajaran Matematika Di Sekolah Dasar di Tengah Pandemi Covid-19. Jurnal Review Pendidikan Dasar: Jurnal Kajian Pendidikan Dan Hasil Penelitian, 6, 125-132. 